\title{
EFFECT OF FINANCIAL REPORTS ON PUBLIC COMPANIES LISTED IN INDONESIA STOCK EXCHANGE
}

\author{
Aba Fransiskus X Lara \\ Faculty Economics and Business, Atma Jaya Catholic University of Indonesia \\ E-mail: fransiskus.lara@atmajaya.ac.id
}

\begin{abstract}
The purpose of this research is to know empirical evidence of several factors affecting Audit Delay. Formulated research problem that is how influence of problematic of transmission of information of company financial report, profitability, solvency, and auditor opinion influence audit delay and added value at property company listed in Indonesia Stock Exchange (IDX). Audit delay is an important issue as it affects the timeliness of the release of the transmission of accounting information. The factors that will be tested in this research are company size, profitability, solvency, and auditor opinion. The population of this study is a property company listed on the Indonesia Stock Exchange period 2014-2016. The results show that the audit delay is between 25 days to 121 days with an average of 77.73 days and a standard deviation of 14,343 . It appears that the average audit delay of the sample companies is still below 90 calendar days which is the limit set by the Financial Services Authority (FSA) in the submission of the financial statements of March 31 of each year. It also appears that there are companies that are late because they have audit delay over 90 days. The lowest Return On Asset (ROA) is owned by PT New Century Development Tbk in 2014, while the highest ROA occurs in 2015 at PT Metropolitan Kentjana Tbk. The Debt to Equity Ratio variable has a minimum value of -2.904703 and a maximum value of 2,466707 with an average of 0.793721 of the sample number of 111 . The lowest solvency ratio is owned by PT New Century Development in 2015, while the highest ratio is at PT. Duta Anggada Realty in 2016.
\end{abstract}

\section{KEY WORDS}

Financial report, property, audit delay, profitability, solvency.

Investment is an investment or money in a particular company in order to gain profit. There are various types of investments commonly used by investors, such as investment deposits, gold investment, or property investment (Anthony and Govindarajan:1995). Of these types of investments have different advantages. Of the three types of investment, property investment is an investment product that has the highest profits. Nevertheless, property investment also requires substantial funds, as property prices are also high. Many investors are choosing to switch to investing in the property sector for higher returns (Bing., et all: 2014: McLaughlin: 1969).

From the perspective mentioned above financial report is a very important tool to obtain information and results achieved by a company (Behn, Choi \& Kang: 2008). In addition, financial report are one important instrument that supports the continuity of a company, especially in companies that have gone public (Carcello \& Nagy:2004; Innes, Brown, \& Hatherly: 1997). One of the obligations of companies that have gone public is to publish financial report that have been prepared with Financial Accounting Standards and have been audited by public accountants registered with the Financial Services Authority (FSA). In Indonesia, the deadline for publicly-listed corporate financial statements is regulated by FSA. The public company must submit its annual financial report accompanied by the auditor's opinion to the FSA and announce it to the public no later than the end of the third month after the date of financial report should be audited within 90 days. which is longer.

The delay in the publication of the financial report is the delay in issuing the financial report at the Indonesia Stock Exchange (IDX) or to the print media. In order to more useful financial report in addition to timely reporting to the public, financial report must also be audited by public accountants (Boyton and Kell: 2003). Thus, the company's management 
has financial report data that can be trusted more accuracy level, for the purpose of decision making and also for the interests of investors because the audited financial report in which contains the company's earnings information serve as one of the basis of decision making the purchase or sale of securities owned investors. That is, the earnings information from the published financial report indirectly leads to an increase or decrease in stock prices.

\section{LITERATURE REVIEW}

Property shows to something commonly known as an entity in relation to the possession of a person or group of persons to an exclusive right (Ahmed, \& Hossain: 2010). The main forms of this property include real property (land), personal property of other physical property, and intellectual property. The right of ownership is related to the property which makes the goods a "belonging to a person" whether private or group, guarantees the owner of his right to do anything to the property in his or her favor, whether to use or not to use it, to transfer ownership of the property. Some philosophers claim that property rights arise from social norms (Carey, \& Simnett:2006). Others say that rights arise from morality or natural law.Modern property ownership rights contain a right of ownership and tenure which is the property of a legitimate individual, even if the individual is not a real person (CheAhmad, \& Abidin: 2008; Henry: 1975). For example in a company, where a company has equal rights with other citizens' rights including constitutional rights, and hence the company is referred to as a legal entity.

Properties typically used in conjunction with union rights include: (i). Control over the use of the property, (ii). Right to any gain from property such as "mining rights", "lease rights", (iii).A rights to transfer or sell property. (iv). A right to own exclusively. The legal system has developed in such a way as to protect transactions and disputes over the use, utilization, transfer and distribution of property, in which the system is included with the socalled contract term (Chen., et all:2011; Hatherly., et all: 1991).

Transmis Implications of Financial Reports and Property Investment. Some of the advantages of investing in property are: (i). Low risk: Property investment has no risk of investment in stock. This is because the movement of property values is not as tight as stocks. If the stock will continue to be based on market conditions and experience a value up and down, while property movements remain stable. That way, this investment is suitable for investors who do not want to get too high risk (Hay: 1998; Jones: 1988). (ii). Have added value: Property will have added value which tend to be big. This added value can be derived from development development, where the property is built on vacant plots then can be used and earn multiple benefits (Pashalian \& Crissy: 1950; Tower, \& Bauer: 1991). For example, a cafe is built on an empty land, but has a strategic location with access to good facilities. In addition, with the strategic location of the property, rental rates will also be different from the suburban property. (iii). Have an increase in profits from year to year: Property will have an increased value from year to year. These benefits are like rent or contract. Each year the rental price or the contract also increases due to the scarcity of land (Moreno \& Casasola: 2016). In addition, for its own sales, property will also continue to rise every year due to the times and currency values. (iv). Can be used as collateral: For investors who have invested property can be used for loan or mortgage application. The advantages of property investment will be easier to get a loan. In this way, investors can reinvest in another property (Chen., et all:2013; Zorio., Garcia-Benau \& Civera:2011).

Transmission of financial reporting is one source of information that communicates the financial condition of the results of the company's operations within a certain period to the parties concerned so that management obtain useful information (Al-Ajmi: 2008). The financial report have the primary objective of providing useful information for economic decision making. Users of financial report will use it to forecast, compare and assess the financial impacts arising from economic decisions it makes.

The following are the users of the financial report and their benefits (Clinch, Stokes, \& Zhu: 2010): (i). Investors: To help determine what action to take in conducting an investment assessment of a company. (ii). Shareholders: To obtain information on share prices and 
other transactions it is necessary for shareholders to determine decisions that may affect the stability of stock prices. (iii). Managers: The rights and obligations of the control holder are exercised by management based on the financial statements.(iv). Employee: Is one factor to be able to achieve company goals. They are interested in information on the stability, profitability and information that allows to assess their ability to provide remuneration, retirement benefits and employment opportunities (Faisal., et all: 2012). (v). Government: As a basis for compiling national income statistics. (vi). Society: The financial report help the community by providing information on the latest trends and developments of the company's prosperity and its range of activities.

Problematic Transmission of Financial Report Information. Audit Delay is the time frame for completion of annual financial report audit, measured by the length of days required to obtain an independent auditor's report on the audit of the company's annual financial report, from the closing date of the company's fiscal year as of 31 December to the date indicated in the independent auditor's report (Al-ghanem \& Hegazy: 2011).

In conducting the audit, it is necessary to have an audit plan, one of which is the formulation of time budget which simply sets the guideline regarding the amount of time from each audit section. The main purpose of the audit is to express an opinion in accordance with generally accepted auditing standards, not to meet the time budget (Garcia-Benau, \& Zorio:2004; Healy; 1977). The direct consequences of unrealized time budgets include late financial reporting.

The size of the company can show how much information is contained therein, while reflecting the awareness of the management of the importance of information, both for external parties and internal companies (Préfontaine., \& Lecavalier: 1990; Zeghal, Maingot \& Tassé:2000). ). Large companies tend to present financial report more timely than small firms. Company size categories are: (1). The Big Company is a company with net worth greater than IDR. 10 Billion including land and buildings. Has more sales than IDR. 50 Billion / year. (2). Medium-sized companies are companies with net worth of IDR. 1-10 Billion including land and buildings. Having sales results greater than IDR. 1 Billion and less than IDR. 50 Billion. (3). A small company is a company with a net worth of at most IDR. 200 million excluding land and building and have minimum sale proceeds of IDR. 1 Billion / year.

Profitability is a performance indicator conducted by management in managing the company's wealth indicated by the profit generated. Broadly speaking, the profits generated by the company come from sales and investments made by the company (Francis, Richard \& Vanstraelen: 2009; Piot: 2005; Pound: 1981). Profitability of a company reflects the level of effectiveness achieved by a company's operations. Rationale that the level of profit used as one way to assess the success of the company's effectiveness is of course related to the final result of the company's policies and decisions that have been implemented by the company in the current period (Fakhfakh: 2013a).

The indicators used to measure the level of profitability is to use the ratio of profit margin, return of assets, return of equity. ROA is usually referred to as the result of a return on total assets. This ratio tries to measure the effectiveness of total resource usage by the company. The profitability level benchmark is ROA that is obtained by the following:

$$
\mathrm{ROA}=\mathrm{EBIT} /(\text { Total Assets }) \times 100 \%
$$

Where: Return on Asset (ROA) - Profitability Ratio Level; EBIT - The amount of net profit after tax; Total Asset $s$ - The number of companies owned by the company.

Solvency is also known as the financial leverage ratio. Measurement is based on the use of liability to shareholder's equity owned by the company. Leverage is a tool used to measure how far a company depends on financing by its creditors against its assets (Fakhfakh:2013b; Hargis, Hernandez \& Hughes:1998).Firms with high leverage mean they are very dependent on outside loans to finance their assets. While companies that have low leverage more finance their investment with their own capital. Based on that, then the management tends to delay the reporting of financial reports containing bad news. Solvency 
benchmarks are debt to equity ratio that compares total assets with total liabilities (either short or long term). Debt to Equity Ratio (DER) can be calculated by the formula:

$$
\text { DER }=(\text { Total Liability }) /(\text { Total Equity }) \times 100 \%
$$

Audit opinion is an independent accountant's opinion on the audited annual financial report of the company. The main information in the audited financial report is the auditor's opinion. Accounting Association (Al-ghanem \& Hegazy: 2011; Amari \& Jarboui: 2013) argues that the audit report is the final step of the entire audit process. Thus the auditor in giving opinion is based on his professional beliefs. There are 5 types of audit opinions that can be given by the auditor of the audited financial statements. (1). Unqualified Opinion: The auditor provides an unqualified opinion if it concludes that the financial statements have been presented fairly. The standard audit report with unqualified opinion can be used if the following conditions are met: all financial report (balance sheets that reflect the position of assets, liabilities and equity, income statement, earnings changes report, cash flow statement and sufficient cash flow). (2). Qualified Opinion: The auditor concludes that the financial report are presented fairly with the exception of certain items (Jones \& Shoemaker:1994; Klare: 1963). ). When an auditor issues a fair report with an exception, the auditor should use the term "except for" in the opinion paragraph. (3). Adverse Opinion: The auditor concludes that the financial report are not presented fairly. An unreasonable opinion is provided only if the auditor is satisfied that the overall financial report presented contain material or misleading misstatements and do not present fairly the financial position or results of operations of the company in accordance with generally accepted accounting principles. This unreasonable opinion is made only if the auditor has sufficient audit evidence (Fakhfakh: 2015a; Smith \& Taffler:1992b). (4). Disclaimer opinion: Does not provide an opinion given by the auditor if the auditor can not conclude whether the financial report have been presented fairly or not. The statement does not provide an opinion given by the auditor if the auditor fails to convince himself that the entire financial report have been presented fairly. (5). Unqualified opinion with explanatory paragraphs and modified wording:

The auditor provides an unqualified opinion with an explanatory paragraph in his audit report because the audits he has performed meet the criteria of a leng ed audit process with satisfactory results and the financial report have been presented fairly. But the auditor feels the need to provide some additional information in the financial report. The following are some of the most important causes of adding explanatory paragraphs in the unqualified audit report: there is no consistency, doubt on going concern, emphasis on something and reports involving other auditors (Fayard: 2006).

Corporate Measurement Parameters and Relationship to Delay Audit. Corporate Size Factor is one of the most frequently researched factors in previous research. Research found a relationship between company size, corporate complexity and quality of internal control with Audit Delay. In this study company size is measured by using total assets. The results found empirical evidence that firm size did not significantly affect the timeliness of financial reporting (Apadore \& Mohd Noor: 2013; Hammami: 2004). Profitability is the company's success in making a profit. So it can be said that profit is good news for the company. The Company will measure the company's ability to generate Profitability from the level of sale, asset, capital or certain shares. The company will not delay the delivery of good news information. Thus companies that are able to generate profits will tend to be more timely delivery of financial report than companies that suffer losses.

Debt to equity ratio (DER) illustrates the comparison of liabilities and equity in the company's funding and shows the capability of the company's own capital to be able to fulfill all its obligations. The higher the DER, the greater the company uses the capital of the creditors. Companies that have large amounts of liabilities tend to urge auditors to start and complete audits more quickly. This is because companies with large liabilities are monitored and monitored by creditors so that it will put pressure on companies to publish audited financial report more quickly to reassure the owners of capital (Fakhfakh: 2015b; Labasse: 1999). From the exposure, the higher the solvency the shorter the audit delay. 
Audit opinion has an effect on the time frame of financial report submitted in audit. Opinions issued by the auditor are based on evidence and invention during field work (Préfontaine \& Lecavalier: 1996). If during the course of the field work the auditor finds no problem or very distorted evidence in accordance with generally accepted accounting principles then the auditor may be able to quickly complete his duties and then issue an audit opinion in accordance with the results obtained, but if the auditor finds irregularities because the financial reporting do not fit with generally accepted accounting principles it is likely that auditors will be looking for more irregularities and other evidences that may ultimately affect the completion of audit time (Gangolly, S., Hussein, Seow, \& Tam:2002).

\section{METHODS OF RESEARCH}

Theoretical relationship between firm size variables, profitability proxyed by ROA, Solvency proxyed with Debt to Equity Ratio, audit opinion, and change. This research is conducted on property companies listed on Indonesia Stock Exchange. The author conducted a study in November 2017 by obtaining data from the official website of Indonesia Stock Exchange. The population of this study are property and real estate companies that have been going public on the Indonesia Stock Exchange and are still listed for 3 consecutive years in 2014 until 2017.

The method of analysis used in this study is statistical analysis method using multiple regression equation, then tested the classical assumption and testing using multiple regression. Classic assumption test and multiple regression testing is done by using software.

\section{RESULTS AND DISCUSSION}

Data analysis is presented in three parts, including descriptive statistical analysis, classical assumption test results, and hypothesis test results. Descriptive statistical analysis describes the dependent variable audit delay and five independent variables that are suspected to affect it.

The analysis is done by comparing the minimum, maximum, and sample values. The following table is the descriptive statistics of audit delay variable and dependent variable scale, ie firm size, profitability, and solvency:

Table 1 - Descriptive Statistics

\begin{tabular}{|lllll|}
\hline & Minimum & Maximum & Mean & Std. Deviation \\
\hline Audit delay & 25 & 121 & 77.73 & 14.343 \\
Total aset & 166677 & 10259171 & 3236493.67 & 1874568.442 \\
ROA & -0.422956 & 0.151034 & 0.030216 & 0.043566 \\
DER & -2.904703 & 2.466707 & 0,793721 & 0.058642 \\
\hline
\end{tabular}

The table shows that the audit delay value is between 25 days to 121 days with an average of 77.73 days and a standard deviation of 14,343 . It appears that the average audit delay of the sample companies is still below 90 calendar days which is the limit set by FSA in the submission of the financial report or the 31st of March of each year. It also appears that there are companies that are late because they have audit delay over 90 days.

The fastest 25-day delay audit experienced by 2014 by PT Alam Sutra Realty Tbk. While the longest delay audit is 121 days, experienced by PT Bhuwanatala Indah Permai Tbk in 2015. The size of the company has a range of values between IDR. 166.67 billion up to IDR.10.26 trillion with an average of IDR. 3.23 trillyun and standard deviation of IDR. 1.87 trillyun. It appears that there is a relatively high fluctuation in the size of the firm in the sample company as measured by the total assets of the firm. 
The size of the company measured by the total minimum assets is owned by PT Bhuwanatala Indah Permai Tbk in 2016, while the maximum size of the company is owned by PT Lippo Karawaci Tbk in 2015. (iv). Profitability ratio measured by Return On Asset ranged from -0.422956 to 0.151034 with an average of 0.030216 and the standard deviation of 0.043566 . Negative value means the company suffered losses so there are companies that suffered losses up to $-42.29 \%$. The average profitability ratio for the sample company is $3.68 \%$. The lowest Return On Asset is owned by PT New Century Development Tbk in 2014, while the highest Return On Asset occurs in 2015 at PT Metropolitan Kentjana Tbk.

Debt to Equity Ratio variable has a minimum value of -2.904703 and a maximum value of 2.466707 with an average of 0.793721 of the total sample of 111 . The lowest solvency ratio is owned by PT. New Century Development in 2015, while the highest ratio is at PT. Duta Anggada Realty in 2016. Testing of data normality in this study using KolmogorovSmirnov non-parametric statistical test by making a hypothesis: HO: residual data is normally distributed and $\mathrm{H} 1$ : residual data is not normally distributed; If the significance value is greater than 0.05 then $\mathrm{HO}$ is accepted, whereas if the significance value is less than 0.05 then $\mathrm{HO}$ is rejected.

Table 2 - Kolmogorov Smirnov One-Sample Normality Test Result Test

\begin{tabular}{|lll|}
\hline One-Sample Kolmogorov-Smirnov Test & & \\
\hline Normal Parameters $^{\mathrm{a}}$ & & Unstandardized Residual \\
& Mean & 77.7297297 \\
Most Extreme Differences & Std. Deviation & 6.43015328 \\
& Absolute & .081 \\
& Positive & .081 \\
Kolmogorov-Smimov Z & Negative & -.059 \\
Asymp. Sig. (2-tailed) & & .849 \\
\hline
\end{tabular}

a. Test distribution is Normal.

From the table above, the magnitude of Kolmogorov-Smirnov (K-S) is 0.849 and the significance at 0.466 so it can be concluded that the data in the regression model has been normally distributed, where the significance value is greater than 0.05 ( $p=0.466>0.05$ ). Hypothesis testing; To find out whether the independent variable in the regression model has an effect on the dependent variable, then tested by using $t$ test ( $t$ test) and $F$ test. Test $F$; To see the effect of total assets, Return On Assets, Debt to Equity Ratio, audit opinion on audit delay simultaneously can be calculated by using $\mathrm{F}$ Test.

Table 3 - Test Results F

\begin{tabular}{|c|c|c|c|c|c|}
\hline \multicolumn{2}{|c|}{ Model } & \multirow{2}{*}{$\begin{array}{l}\text { Sum of Squares } \\
4548.156\end{array}$} & \multirow{2}{*}{$\frac{D f}{5}$} & \multirow{2}{*}{$\begin{array}{l}\text { Mean Square } \\
909.631\end{array}$} & \multirow{2}{*}{$\begin{array}{l}F \\
5.282\end{array}$} \\
\hline & Regression & & & & \\
\hline \multirow[t]{2}{*}{1} & Residual & 18081.736 & 105 & 172.207 & \\
\hline & Total & 22629.892 & 110 & & \\
\hline
\end{tabular}

a. Predictors: (Constant), Pergantian , ROA, Total aset, DER, Opini audit

b. Dependent Variable: Audit delay

From the table above, it appears that the value of $\mathrm{F}$ arithmetic on the research model of 5.282 with a significance level of 0.000 . The value of significance is below 0.05 indicating that the independent variables simultaneously have a significant influence on audit delay. $T$ test; The significance test of individual parameters, also called statistical test $t$ is the test 
used to see the effect of partial independent variables on the dependent variable. Here is the result of calculating the value of $t$ arithmetic and significance level in this research.

Table 4 - Test Results t

\begin{tabular}{|c|c|c|c|c|c|c|c|}
\hline \multirow[b]{2}{*}{ Model } & \multicolumn{2}{|c|}{ Unstandardized Coefficients } & \multicolumn{2}{|c|}{ Standardized Coefficients } & \multicolumn{3}{|c|}{ Collinearity Statistics } \\
\hline & $B$ & Std. Error & Beta & $\mathrm{t}$ & Sig. 7 & Tolerance & VIF \\
\hline 1 (Constant) & 91.093 & 4.645 & & 19.610 & .000 & & \\
\hline Total aset & $-2.412 \mathrm{E}-6$ & .000 & -.315 & -3.569 & .001 & .975 & 1.025 \\
\hline ROA & -.616 & .305 & -.187 & -2.020 & .046 & .888 & 1.126 \\
\hline DER & -.018 & .022 & -.073 & -.830 & .409 & .974 & 1.027 \\
\hline Opini audit & -6.718 & 3.596 & -.173 & -1.868 & .065 & .883 & 1.132 \\
\hline
\end{tabular}

a. Dependent Variable: Audit delay

From result of $t$ test can be seen the amount of $t$ hitung for asset total variable is $3,569<-t$ tabel $(-1,9815)$, and value of research significance equal to $0,001<0,05$. The above shows the total asset has a significant effect on audit delay. So it can be concluded H_1 (The first hypothesis) is accepted, The above table also shows the amount of thitung for the variable Return On Asset of $-2.020<-t$ table $(-1,9815)$, and significance value 0.046 $<0.05$. It means Return On Asset (ROA) has an effect on audit delay. So it can be concluded H_2 (second hypothesis) accepted.

The value of $t$ hitung for Debt to Equity Ratio variable is $-0,830<-t$ tabel $(-1,9815)$ and significance value $0,409>0,05$ ). This means that Debt to Equity Ratio (DER) has no significant effect on audit delay. So it can be concluded H_3 (third hypothesis) rejected. While the nilait_hitungvariable audit opinion is $-1,868<-t$ table $(-1,9815)$ and significance value is $0,065>0,05$. This means that audit opinion does not significantly influence audit delay then $\mathrm{H}_{-} 4$ (fourth hypothesis) is rejected.

\section{CONCLUSION}

In conducting investment activities, investors need to first look at the company's financial statements to ensure that investors will choose the right stock. The financial statements are the main benchmark in measuring the growth of the property company's profit, because the company's operating profit will have a significant effect on the growth of the company's stock.

In general, auditing is a systematic process of obtaining and evaluating objectively objective statements about economic activities and events, with a view to establishing the degree of conformity between the statements with predetermined criteria, and the delivery of the results to the interested users (Azubike \& Aggreh:2014; Li: 2008). The general audit objective of the auditor's financial statements is to express an opinion on the fairness in all material matters, the financial position of business results and cash flows in accordance with accounting principles generally accepted in Indonesia.

Profitability ratio measured by Return On Asset ranged from -0.422956 to 0.151034 with an average of 0.030216 and the standard deviation of 0.043566 . Negative value means the company suffered losses so there are companies that suffered losses up to $-42.29 \%$. The average profitability ratio for the sample company is $3.68 \%$. The lowest Return On Asset is owned by PT New Century Development Tbk in 2014, while the highest Return On Asset occurs in 2015 at PT Metropolitan Kentjana Tbk. Debt to Equity Ratio variables have a minimum value of -2.904703 and a maximum value of 2.466707 with an average of 0.793721 from the number of samples of 111 . The greater the profitability ratio of the company, the 
better the profits to be generated by the company. Companies that experience profits tend to report information from their financial statements more quickly than firms with lower profit levels.

The lowest solvency ratio is owned by PT New Century Development in the year 2015, while the highest ratio is at PT D uta Anggada Realty in 2016. From the result of t test can be seen the amount of $t$.hitung for asset total variable is $-3,569<-t$ table $(-1,9815)$, and value of research significance equal to $0,001<0,05$. The above shows the total asset has a significant effect on audit delay. So it can be concluded H_1 (The first hypothesis) is accepted. Debt to equity ratio (DER) illustrates the comparison of liabilities and equity in the company's funding and shows the capability of the company's own capital to be able to fulfill all its obligations.

\section{REFERENCES}

1. Anthony, R.N and Govindarajan, (1995),“Management Control System”, Eight Edition, Irwin, Chicago.

2. Ahmed, A., \& Hossain Md, S. (2010). Audit report lag: A study of the Bangladeshi listed companies. ASA University Review, 4.

3. Al-Ajmi, J. (2008). Audit and reporting delays: Evidence from an emerging market. Advances in Accounting, incorporating Advances in International Accounting, 24, 217226.

4. Al-ghanem, W., \& Hegazy, M. (2011). An empirical analysis of audit delays and timeliness of corporate financial reporting in Kuwait. Eurasian Business Review, 1, 73 90.

5. Amari, M., \& Jarboui, A. (2013). Financial reporting delay and investors behavior: Evidence from Tunisia. International Journal Management Business Research, 3, 57-67.

6. Apadore, K., \& Mohd Noor, N. (2013). Determinants of audit report lag and corporate governance in Malaysia. International Journal of Business and Management, 8, 18338119.

7. Azubike, J., \& Aggreh, M. (2014). Corporate governance and audit delay in Nigerian quoted companies. European Journal of Accounting Auditing and Finance Research, 2, 22-33.

8. Behn, B. K., Choi, J., \& Kang, T. (2008). Audit quality and properties of analyst earnings forecasts. The Accounting Review, 83, 327-349.

9. Bing, J., Xin Huang, C., Li, A., \& Zhu, X. (2014). Audit quality research report, Australian National Centre for Audit and Assurance Research, Canberra.

10. Boyton, WC and G. Kell, (2003), "Modern Auditing", Seventh Edition, John Wiley \& Sons, Inc, New York.

11. Carcello, J. V., \& Nagy, A. L. (2004). Client size, auditor specialization and fraudulent financial reporting. Managerial Auditing Journal, 19, 651-668.

12. Carey, P., \& Simnett, R. (2006). Audit partner tenure and audit quality. The Accounting Review, 81, 653-676.

13. Che-Ahmad, A., \& Abidin, S. (2008). Audit delay of listed companies: A case of Malaysia. International Business Research, 1, 32-39.

14. Chen, H., Chen, J. Z., Lobo, G. J., \& Wang, Y. (2011). Effects of audit quality on earnings management and cost of equity capital: Evidence from China. Contemporary Accounting Research, 28, 892-925.

15. Chen, Y., Hsu, Y., Huang, M., \& Yang, P. (2013). Quality, size and performance of Audi firms. The International Journal of Business and Finance Research, 7, 89-105.

16. Clinch, G., Stokes, D. J., \& Zhu, T. (2010). Audit quality and information asymmetry between traders.

17. Faisal, S., Mishari, M., Eyad, A., \& Saad, S. (2012). Dual/joint auditors and the level of compliance with international financial reporting standards (IFRS-required disclosure): The case of financial institutions in Kuwait. Journal of Economic and Administrative Sciences, 28, 109-129. 
18. Fakhfakh, M. (2013a). The readability of standardized reports by the international federation of accountants. Journal of Commerce and Accounting Research, 2, 10-28.

19. Fakhfakh, M. (2013b). Linguistic performance and comprehensibility of auditors' reports in Tunisia. The IUP Journal of Accounting Research and Audit Practices, 12, 30-56.

20. Fakhfakh, M. (2015a). The readability of international illustration of auditor's report: An advanced reflection on the compromise between normative principles and linguistic requirements. Journal of Economics, Finance and Administrative Science, 20, 21-29.

21. Fakhfakh, M. (2015b). Legibility of unmodified audit report on consolidated financial statements: A normative analysis under the International standardization (Working Paper). Tunisia: University of Sfax.

22. Fayard, L. (2006). Techniques de Communication, synthèse du cours, Paris1-Sorbonne, UFR-mastère de techniques quantitatives et expertise économique [Commnication techniques, synthesis of course, Paris 1-Sorbonne UFR-Masters quantitative techniques and economic expertise].

23. Francis, J. R., Richard, C., \& Vanstraelen, A. (2009). Assessing France's joint audit requirement: Are two heads better than one? Auditing: A Journal of Practice and Theory, $28,35-63$.

24. Gangolly, S., Hussein, M. E., Seow, G. S., \& Tam, K. (2002). Harmonization of the auditor's report. The International Journal of Accounting, 37, 327-346.

25. Garcia-Benau, M. A., \& Zorio, A. (2004). Audit reports on financial statements prepared according to IASB standards: Empirical evidence from the european union. International Journal of Auditing, 8, 237-252.

26. Hammami, H. (2004). Facilite de lecture des rapports annuels: Evlauation des informations comptables textuelles-résultats préliminaires du contexte italien. Actes du Congrès de l'Association Française de Comptabilité.

27. Hargis G., Hernandez A. K., \& Hughes P. (1998). Developing quality technical information: A handbook for writers and editors. Upper Saddle River, NJ: Prentice Hall.

28. Hatherly, D., Innes, J., \& John \& Brown, T. (1991). The expanded audit report-an empirical investigation. Accounting and Business Research, 21, 311-319.

29. Hay, D. (1998). Communication in auditors' reports: Variations in readability and the effect of audit firm structure. Asia Pacific Journal of Accounting, 5, 179-197.

30. Healy, P. (1977). Can you understand the footnotes to financial statements? Accountants' Journal, 56, 219-222.

31. Henry, G. (1975). Comment mesurer la lisibilité [How to measure readability]. Paris: Fernand Nathan, Editions Labor.

32. Innes, J., Brown, T., \& Hatherly, D. (1997). The expanded audit report: A research study within the development of SAS 600. Accounting, Auditing and Accountability Journal, 10, 702-717.

33. Jones, M. J. (1988). A longitudinal study of the readability of the chairman's narratives in the corporate reports of a UK Company. Accounting and Business Research, 18, 297305.

34. Jones, M. J., \& Shoemaker, P. A. (1994). Accounting narrative: A review of empirical studies of content and readability. Journal of Accounting Literature, 13, 142-184.

35. Klare, G. R. (1963). The measurement of readability. Ames, IA: lowa State University Press.

36. Labasse, B. (1999). La lisibilité rédactionnelle: fondements et perspectives. Communication et langages, 121, 86-103.

37. Li, F. (2008). Annual report readability, current earnings, and earnings persistence. Journal of Accounting and Economics, 45, 221-247.

38. McLaughlin, G. H. (1969). SMOG grading-a new readability formula. Journal of Reading, 12, 639-646.

39. Moreno, A., \& Casasola, A. (2016). A readability evolution of narratives in annual reports: A longitudinal study of two Spanish companies. Journal of Business and Technical Communication, 30, 202-235. 
40. Pashalian, R., \& Crissy, J. E. W. (1950). How readable are corporate annual report? Journal of Applied Psychology, 34, 244-248.

41. Piot, C. (2005). La date du rapport des commissaires aux comptes: Un compromis entre contraintes liées à la mission d'audit et exigences informationnelles? Congrès IAAER, 29-30 septembre, Bordeaux.

42. Pound, G. D. (1981). A note on audit report readability. Accounting and Finance, 21, 4555.

43. Préfontaine, C., \& Lecavalier, J. (1990). La mesure de la lisibilité et de l'intelligibilité des textes [Measuring the readability and comprehensibility of the texts]. Communication présentée à l'Association pour le développement de la mesure et de l'évaluation en éducation [Paper presented at the Association for the Development of measurement and evaluation in education (ADMEE)], Montréal.

44. Préfontaine, C., \& Lecavalier, J. (1996). Analyse de l'intelligibilité de textes prescriptifs [Analysis of the intelligibility of prescriptive texts]. Revue québécoise de linguistique: Lisibilité et intelligibilité [Quebec language magazine: readability and comprehensibility], $25,100-141$.

45. Smith, M. \& Taffler, R. (1992b). Readability and understandability: Different measures of the textual complexity of accounting narrative. Accounting, Auditing and Accountability, $5,84-98$.

46. Tower, G., \& Bauer, L. (1991). An empirical study of communication in New Zealand audit reports: contrasting the public and private sectors. Annual Conference Proceedings. Brisbane: Accounting Association of Australia and New Zealand.

47. Zeghal, D., Maingot M., \& Tassé M (2000). Readability of the auditor's report: An international comparison. European Accounting Association Annual Conference.

48. Zorio A., Garcia-Benau M. A., \& Civera J. N. (2011), Readability of clarified ISAs and explanatory factors. The 6th European Auditing Research Network Symposium, Hosted by Norwegian School of Economics $(\mathrm{NHH})$, Bergen, Norway. 